DOI: $10.17805 /$ zpu.2017.1.3

\title{
Женщина в науке и философии: доминирующие мифы и действительность
}

\author{
А. В. КОСТИНА \\ МОСКОВСКИЙ ГУМАНИТАРНЫЙ УНИВЕРСИТЕТ
}

В данной статье автор выделяет несколько стереотипов, которые образуют систему мифов о женщинах - ученых и философах в обществе, анализирует их и доказывает их несостоятельность.

Миф №1 «Главное предназначение женщины - совмещать функции жены и матери, при этом совмещение занятий наукой или философией с выполнением этих главных функций для нее невозможно». Среди докторов наук, и тем более академиков женщин, действительно, не так много. Но факт малого присутствия женщин в науке доказывает как раз то, что они стремятся к рождению и воспитанию детей и отказываются от научной карьеры в пользу реализации своих природных функций. Здесь необходимо также учитывать условия развития науки в разных странах.

Миф №2 «Женщина - ученый или философ должна обладать сильным характером, но все женщины слишком эмоциональны». Эмоциональность и даже слезы присущи в равной степени и женщинам, и мужчинам, и стереотип об излишней эмоциональности женщин является мифом. Характерно, что мужчины за излишнюю эмоциональность не подвергаются обструкции так же, как женщины, напротив, встречают всяческую поддержку.

Миф №3 «Женщина не может быть гением. В науке и философии практически нет открытий, сделанных женщинами». Миф определяется и сегодня позицией мужской апологетики. Добиться тех же результатов, которых добиваются мужчины в науке и философии, женщине гораздо труднее - ей необходимо не только подтверждать свою научную компетентность, но и сохранять свое право на само научное высказывание, на включенность в научный и философский дискурс. 
Приводится целый ряд открытий, сделанных в мировой науке женщинами, дан список имен известных ученых-женщин. Отмечается, что недооценка вклада женщин в науку является мировым трендом. Более того, специальные исследования показывают, что масса открытий, сделанных женщинами, были или недооценены их коллегами-мужчинами или были подтверждены исследованиями и представлены как собственные.

В науке России половину кадрового состава в химии, биологии, географии, медицине, сельском хозяйстве, архитектуре, фармакологии, гуманитарных науках (кроме истории) составляют женщины. Совмещение чисто женских функций - например, функции материнства, и научной деятельности дается весьма сложно. Однако женщины - ученые и философы продолжают эффективно заниматься научными исследованиями.

Ключевые слова: женщина; стереотип; миф; гендер; феминность, маскулинность; женщина в науке; женщина-философ

\section{ВВЕАЕНИЕ}

$\mathrm{C}$ тереотип, согласно которому философия и наука являются чисто мужскими сферами профессиональной деятельности, достаточно распространен. Хотя ситуация подчеркивания мужского доминирования ярко проявляет себя практически во всех профессиях, опирающихся на интеллект, - не только в науке и философии, но и в политике, менеджменте. К примеру, при описании женщин-политиков серьезный российский журнал «Профиль» прибег к такой риторике: «Очки в модной тонкой оправе. Свежее декольте. Новая коллекция. Одной только полупрозрачной кофточки, в которой тогда еще заместитель министра финансов Голикова однажды появилась на заседании правительства, достаточно, чтобы почувствовать: тренд меняется. Брюнетка Набиуллина и блондинка Голикова неожиданно заставили по-иному посмотреть на женщин во власти» (Арифджанов, 2007: Электронный ресурс). В этом описании нет ничего о профессионализме, зато есть упоминание о декольте, цвете волос, модных брендах. Трудно представить аналитическую статью, содержащую подобные высказывания и посвященную главе МИА Сергею Ааврову или министру обороны России Сергею Шойгу.

Такое восприятие отражает доминирующие в обществе мифы о женщинах в науке и философии. Проанализируем их.

\section{МИФ ПЕРВЫЙ}

Миф №1. Женшинам в науке делать нечего - женшинь-ученые в большинстве своем бездетнь. Женшина должна вьполнять функиии жень и матери - это главное предназначение женшины, при этом совмещение занятий наукой или философией с выполнением этих главных функиий для женшины невозможно.

Аля России подобная постановка вопроса чрезвычайно актуальна, так как архетип Матери является системообразующим в системе представлений каждого россиянина. И аргумент, связанный с невозможностью женщины оставаться женой и матерью, является весьма негативным для формирования образа женщины - ученого или философа. В СМИ образ ученого и образ матери оказываются несовместимыми. Причем это характерно как для западных, так и для российских СМИ. В научном альманахе Венского института демографии приводится статистика, согласно которой $44 \%$ женщин-ученых в возрасте 40-45 лет не имеют детей, у остальных 56\% на каждую женщину приходится 0,9 ребенка (т. е. каждая десятая женщина бездетна) (Buber at al., 2011: Электронный ресурс). В целом же у женщин, занимающихся академической наукой в Австрии и Германии, уровень бездетности, действительно, чрезвычайно высок - он достигает 45-60\%, что подтверждается исследованиями разных лет. 
Не опровергая данные исследования, приведенные в Венском научном альманахе, обратимся к более мягкой, но все равно тревожной статистике: в Польше $25 \%$ женщин-ученых не имеют детей, в Швеции - около $20 \%$, во Франции и Испании - $10 \%$. Согласно российской статистике, вероятность остаться бездетной у женщины с дипломом или, тем более, с ученой степенью, в два раза выше, чем у домашней хозяйки. И возраст рождения первенца у таких женщин -29 лет, что на пять лет позже, чем у женщин с менее высокой квалификацией (Пронин, 2008: Электронный ресурс). Тем не менее наука остается престижной сферой деятельности для женщин в России если женщины-ученые составляют в Швеции, Франции, Великобритании и Германии около 20\%, то в России - около 30\%, столько же, сколько в США и Канаде. Вместе с тем среди докторов наук и тем более академиков представительниц прекрасного пола, действительно, не так много.

Но факт малого присутствия женщин в науке доказывает как раз то, что они стремятся к рождению и воспитанию детей и отказываются от научной карьеры в пользу реализации своих природных функций. Здесь необходимо также учитывать условия развития науки в разных странах, если в Германии научная работа в неинституциализированных условиях - например, дома, невозможна, то, к примеру, в России - это распространенная практика. Более того, защита кандидатской диссертации в Германии предполагает заключение с соискателем короткого одно-двухгодичного контракта, после нескольких подобных контрактов он может сдать своеобразный экзамен теньюр, подтвердив свою научную состоятельность через научные достижения, публикации и выступления. Получение теньюр означает обеспечение социального статуса и невозможность увольнения данного сотрудника, что и определяет высокую привлекательность этого научного уровня. Однако в Германии и Австрии теньюр могут получить только профессора - т. е. ученые 40-45 лет, что для женщины означает выбор в пользу профессии, а не семьи. В значительной степени этим обстоятельством определяется малое число женщин на самых высоких уровнях научных институций.

Эта проблема широко обсуждается в Интернете, и мнений по этому вопросу очень много. Среди них следующие:

- ситуация такова исключительно по причине дикой государственной политики, когда детсадов мало, дорогих и плохих, поддержки работающим родителям практически никакой;

- многие женщины в научной среде подолгу не рожают именно из-за этого - на несколько лет выпадаешь из профессии, так как детсадов очень мало, и они дорогие, а после выпадения туда почему-то сложно вернуться;

- не работать женщине в Германии экономически выгоднее, так как в этом случае семья платит меньше налогов, и общий семейный доход получается выше, чем когда работают оба, - это политика стимулирования рождаемости.

Высказывания в Сети не всегда соответствуют фактам, но они чрезвычайно важны, так как точно отражают общественную реакцию на те или иные явления.

Но вне зависимости от мнения респондентов очевидно, что занятия воспитанием детей и ведение домашнего хозяйства являются очень трудоемкими, а совмещение занятий наукой и домашним хозяйством - чрезвычайно затруднительно. Участница форума Feministki в «Живом журнале» (LiveJournal) рассказывает: «...отец моего шефа сам большой ученый. И при этом отец пятерых детей....Он говорит, что один ребенок в среАнем равен четырем статьям (область - молекулярная биология). В том смысле, что ты их не напишешь из-за ребенка» (Миф о бездетности ... : Электронный ресурс). И ос- 
новная масса женщин вне зависимости от профессии предпочитают быть домохозяйками только на время воспитания детей, а затем - возвращаться к профессиональным занятиям (Пронин, 2008: Электронный ресурс). Те же женщины, которые решили посвятить себя науке, часто жертвуют материнством в пользу развития научной карьеры.

Именно эти обстоятельства определяют тот факт, что распределение высших академических званий осуществляется в пользу мужчин, и чем выше научный статус, тем меньше женщин присутствует на данном уровне. Ассоциация женщин в науке (Association for Women in Science, AWIS) исследовала причины, по которым между защитой $\mathrm{PhD}$ и получением звания ординарного профессора (Full Professor) уходят из науки женщины. Исследователи образно назвали этот процесс «утечками из трубы академической карьеры» среди женщин (Сычева, 2012: Электронный ресурс). Согласно данным Ассоциации, рождение ребенка приводит к уходу из науки 29\% женщин, оформление брака и принятие на себя обязанностей жены - 20\%, при соискании должности адъюнкт-профессора и заключении постоянного контракта у женщин на $23 \%$ меньше возможности получить данную должность, чем у мужчины, та же зависимость - при получении должности Full Professor (см. таблицу).

Конечно, эти данные нельзя абсолютизировать хотя бы по той причине, что позицию, связанную с выбором кандидатов на должность, невозможно сопоставлять с абсолютными значениями, показывающими уход женщины в отпуск по уходу за ребенком или увольнение в связи с выходом замуж. Но общую тенденцию эти данные отражают в полной мере.

Конечно, ситуация в Германии не универсальна. Вот одно из мнений участниц форума: «...во Франции все совершенно по-другому. Среди ученых дам, причем очень высокого уровня, распространена многодетность: у одной из самых уважаемых моих коллег Claire Voisin пятеро детей, у другой, тоже очень известной Laure SaintRaymond, работающей в смежной области, - шестеро. Хотя бы трое, наверное, у половины. Рождаемость среди ученой публики выше, чем в среднем по стране» (Миф о бездетности ... : Электронный ресурс). Того же мнения придерживался известный

ПРИСУТСТВИЕ ЖЕНЩИН В НАУКЕ И ПРИЧИНЫ УХОАА ИЗ НЕЕ, \% PRESENCE OF WOMEN IN SCIENCE AND REASONS OF LEAVING IT, IN \%

\begin{tabular}{|c|c|c|c|c|c|}
\hline $\begin{array}{c}\text { Присутствие } \\
\text { в науке }\end{array}$ & $\begin{array}{c}\text { Поступление } \\
\text { в вуз }\end{array}$ & \multicolumn{2}{|c|}{$\begin{array}{c}\text { Получение } \\
\text { степени PhD. } \\
\text { Ассистент- } \\
\text { профессор, срочньй } \\
\text { контракт }\end{array}$} & $\begin{array}{l}\text { Адъюнкт- } \\
\text { профессор, } \\
\text { постоянньии } \\
\text { контракт }\end{array}$ & $\begin{array}{c}\text { Профрессор } \\
\text { (Full Professor), } \\
\text { nостоянный } \\
\text { контракт }\end{array}$ \\
\hline $\begin{array}{l}\text { Общее число } \\
\text { женщин } \\
\text { в науке, \% }\end{array}$ & 100 & \multicolumn{2}{|c|}{51} & 28 & 3 \\
\hline Отсев, \% & - & 29 & 20 & 23 & 25 \\
\hline Причины отсева & - & $\begin{array}{c}\text { Рождение } \\
\text { ребенка }\end{array}$ & $\begin{array}{c}\text { Оформление } \\
\text { брака }\end{array}$ & $\begin{array}{c}\text { У женщин на } 23 \% \\
\text { меньше шансов } \\
\text { получить данную } \\
\text { должность, } \\
\text { чем у мужчин }\end{array}$ & $\begin{array}{c}\text { У женщин на 25\% } \\
\text { меньше шансов } \\
\text { стать } \\
\text { профессором } \\
\text { в течение } \\
\text { максимум } 16 \text { лет, } \\
\text { чем у мужчин }\end{array}$ \\
\hline
\end{tabular}


ученый И. И. Мечников, который более 100 лет назад высказался по этому вопросу в пользу женщин: «Большая часть ученых женщин обнаруживает несомненную склонность к супружеству и к семейной жизни вообще. Ааже женщины, наиболее отличившиеся как ученые, не составляют исключения из этого правила» (Мечников, 1988: 196-197). Наиболее известные примеры, как пишет Мечников: знаменитая г-жа Кюри, имевшая двух детей, и столь же прославившаяся в математике Софья Васильевна Ковалевская, которая, как известно, тоже была матерью.

Таким образом, бездетность женщин - ученых и философов является мифом малое количество детей или их отсутствие есть следствие трудной совместимости материнства и занятий научной работой, в равной мере трудоемких.

\section{МИФ ВТОРОЙ}

Миф №2. Женщина - ученый или философ должна обладать сильным характером, но все женшины слишком эмочиональны.

Этот стереотип воспроизводится весьма часто. Один из свежих примеров - это высказывание Нобелевского лауреата сэра Тима Ханта о женщинах-ученых в лабораториях. The Independent так передает слова Т. Ханта: «Аавайте я поделюсь с вами трудностями, которые я испытываю с девушками. Три вещи случаются, когда они в лаборатории: ты влюбляешься в них, они в тебя влюбляются, и они начинают плакать, если ты их критикуешь» (Bushanan, 2015: Электронный ресурс). TIME, The Independetn, Huffington Post гневно откликнулись на это заявление ученого, а в соцсетях появились такие сообщения:

- «Сегодня хотела поработать, но теперь слишком занята тем, что влюбляю себя в преимущественно мужской отдел»;

- «Мужчинам не место в лабораториях. На них накатывают эмоции и страх, когда они видят твои слезы. И они пытаются изолировать тебя от всего отдела»;

- «Почти закончила черновой вариант работы по физике, но ничего не вижу сквозь слезы (Нобелевский лауреат ..., 2015: Электронный ресурс).

Общество отнеслось к высказываниям ученого отрицательно, а Королевское общество, членом которого является Хант, специально указало, что мнение остальных его членов не совпадает с мнением Ханта. Большая часть ученых интерпретировала слова Ханта как утверждение несовместимости женщины и научной работы в лаборатории и отреагировала на них чрезвычайно негативно (там же). Хант принес извинения за свои высказывания, однако еще раз подтвердил то, что работе в лаборатории мешают личные привязанности и излишняя эмоциональность. Таким образом, свою убежденность в невозможности занятия женщинами научной работой Хант сохранил.

Характерно, что практически в то же время в Интернете обсуждалась ситуация, имеющая непосредственное отношение к вопросу об излишней эмоциональности в научной сфере. Ученый миссии Rosetta доктор Мэтт Тейлор, посадивший космический аппарат на комету, во время рассказа о своем проекте был в рубашке с изображением девушек в шортах. Тейлор был обвинен в сексизме, и во время конференции Европейского космического агентства он публично принес извинения за «сексистскую рубашку». Причем эти извинения носили чрезмерно эмоциональный характер - известный ученый, осуществивший прорыв в космических технологиях, во время извинений за «сексистскую рубашку» откровенно прослезился. Желание поддержать Тейлора вызвало целое движение в Facebook - в соцсети была создана страница «10 тысяч лайков для Мэтта Тейлора», однако за несколько дней она собрала их свыше 23 тысяч. 
Характерно, что слезы Тейлора не создали негативного имиджа ученого. Напротив, и мужчины, и женщины выложили в Сети высказывания примерно такого содержания:

- «Позор Европейскому космическому агентству, они должны были вступиться за него... многие женщины не пойдут в науку из-за рубашки? - что ж, если эти девушки настолько глупы, наука в любом случае далека от их устремлений. Аоктор Мэтт Тейлор, Вы так многого достигли, пожалуйста, не дайте им это разрушить! Поздравления великому ученому и классному мужчине!» - пишет пользовательница Елена Радугина (Трусова, 2014: Электронный ресурс);

- «Я уже не феминистка, но я никогда не ненавидела мужчин, когда была ей. ...Я думаю, рубашка была надета парнем, который праздновал огромное достижение человечества. Не чувствуйте себя плохо за свой выбор, доктор Тейлор!» - считает Аиза Поттер (там же).

Этот пример показывает, что эмоциональность и даже слезы присущи в равной степени и женщинам, и мужчинам, и стереотип об излишней эмоциональности женщин является мифом. Причем характерно, что мужчины за излишнюю эмоциональность не подвергаются обструкции, как женщины, напротив, встречают всяческую поддержку.

\section{МИФ ТРЕТИЙ}

Миф №3. Женшина не может быть гением. В науке и философии практически нет открытий, сделанных женщинали. Женщина - ученый или философ - все равно женщина. Внешность для нее гораздо важнее, чем научная работа и докладь. В противном случае она имеет все признаки мужиинь - начиная от визуального мужеподобного облика и завершал мужским складом ума.

В 1990-е годы в России все буквально зачитывались книгой 23-летнего австрийского философа Отто Вейнингера (1880-1903) «Пол и характер». Книга вызывала массу споров и волну пессимизма у женщин по причине того, что автор - молодой, блестящий, перспективный (правда, покончивший с собой по неизвестной причине) - доказывал неполноценность женщин. Одним из его аргументов было то, что гениальных женщин по сравнению с числом мужчин-гениев практически нет. Те же женщины, которые были успешны в науке и философии, имели мужеподобную внешность и мужские черты характера. Подтверждая свой тезис, Вейнингер ссылался на внешность и характер Елены Блавацкой и Софьи Ковалевской.

В эту же риторику укладывается стереотип о том, что женщина не может заниматься наукой и философией самостоятельно - она нуждается в поддержке и опоре выдающихся и влиятельных мужчин. Причем точно так же, как и в политике, где, к примеру, Сеголен Руаяль, Хиллари Клинтон, Кристина Киршнер долгое время воспринимались как креатуры их мужей или покровителей. Аействительно, многие женщины, занимающиеся философией, вошли в историю как последовательницы идей прославленных ученых. Аостаточно вспомнить Феано - жену Пифагора, Ксантиппу - жену Сократа, Гипархию - супругу философа-киника Кратета Фиванского, Аксиофею - ученицу Платона, Гипатию Александрийскую, обучавшуюся под руководством своего отца, Теона Александрийского. К сожалению, сочинения женщинфилософов не сохранились, что дает основание исследователям говорить об их несамостоятельности и интерпретационности.

Аействительно, Средневековье, Возрождение, Просвещение - все эти эпохи не дают примера деятельности женщин - ученых или философов. Но какова причина этого? 
Ажейн Гримшау, посвятившая анализу этого факта свое исследование, выделила ряд особенностей философских систем Аристотеля и $\Lambda$ окка. Автор обозначила три черты исследований данных авторов, которые имеют практически универсальный для «мужской» философской традиции характер. «Во-первых, это явное или неявное исключение женщин из области философского изучения. Во-вторых, открытая или завуалированная проповедь мужского превосходства. И третьим таким свойством ей представляется возможность использования теорий из истории философии для «научного» обоснования зависимой, подчиненной роли женщины» (Валянская, 2015: Электронный ресурс).

Подобная ситуация является весьма традиционной - содержание научной теории всегда согласуется с тем социокультурным контекстом, в котором она складывается и формируется. Аействительно, содержание любой научной теории актуально в определенной среде - культурной, идеологической, социально-политической. Сказанное, естественно, не означает, что взгляды ученого полностью детерминируются общественно-политической доминантой. И тем не менее преобладающие в обществе идеи и представления, в которых отражается обобщенный социально-исторический опыт и выражается определенное отношение к действительности, безусловно, оказывают влияние на позицию исследователя - вне зависимости от того, осознается это влияние им самим или нет.

В мускулинном обществе, где права женщины были ничтожными - чуть больше в античной Греции и Риме, меньше - в средневековой Европе, еще меньше - в восточных деспотиях, примерами удивительного мужества и воли выглядят научные и философские искания женщин. Чаще же женское право на высказывание принимает форму все той же мужской апологетики, как в трактате I в. китаянки Пань Хоэпан, который содержит следующие наставления: «Мы занимаем последнее место в человеческом роде, мы составляем его слабую сторону - это истина, в которой мы должны быть твердо убеждены... Не станем ожидать, чтобы горький опыт показал нам помимо нашего желания, что мы такое. Убедимся в этой истине как можно ранее для того, чтобы во всем сообразовываться с нею» (там же).

Не удивительно, что и философская традиция - фактически мужская - осмысливает женщину в категориях подчинения, неполноценности, вторичности, естественности (в противовес культурности), чувственности (в противовес гражданской добродетельности). Ааже Платон, который (в отличие от Аристотеля, считавшего женщину ошибкой природы) в современной западной философии получил статус феминиста, иронизировал: «Насколько женская природа по своему достоинству хуже нашей, мужской, настолько же она превосходит нас своей многочисленностью» (там же). Уже здесь коренятся истоки мифа о нравственном и интеллектуальном превосходстве мужчин. Насколько жива эта традиция, позволяет судить широко известное высказывание выдающего современного философа В. М. Межуева о том, что сущность женщины определяется категориями эстетического, а мужчины - этического.

Естественно, что в рамках религиозного Средневековья, где философия выступает в виде богословия и экзегетики, эта традиция развивается. И несмотря на то что вопрос о возможности восприятия женщины как человека и применения к ней слова hото был положительно решен в 585 г. на Маконском соборе, эта проблема оставалась предметом обсуждения фактически до начала эпохи Возрождения с ее системообразующим понятием гуманизма. И если фраза «Женщина - тоже человек» воспринимается сегодня как высказывание юмористическое, то отношение к женщине как 
к обладательнице облегченного варианта мужского интеллекта остается актуальным (вспомним высказывание о блондинках как «светлых головах»).

Поэтому миф о несамостоятельности женщины-ученого и женщины-философа определяется и сегодня позицией мужской апологетики. Аобиться тех же результатов, которых добиваются мужчины в науке и философии, женщине гораздо труднее - ей необходимо не только подтверждать свою научную компетентность, но и сохранять свое право на само научное высказывание, на включенность в научный и философский дискурс.

\section{ВКААА ЖЕНЩИН В МИРОВУЮ НАУКУ}

Наталья Пушкарева, исследующая историю дискриминационных практик в отношении женщин-ученых, приводит целую серию открытий, сделанных женщинами. Это и «астролябия - прибор, позволяющий определять положение планет относительно Солнца (ее изобрела Гипатия из Александрии в 370 г. до н. э.), и перископ, без которого не может обходиться подводная лодка (изобретение американки Сары Метер, 1845 г.). Николь Барбье Клико изобрела еще в конце XVIII в. "розовое шалпанское», метод приготовления которого основан на принципе вторичного брожения в герметически закупоренном сосуде - так появилось шампанское «Вдова Клико». Ее младшая современница королева Англии Анна предложила в 1702 г. идею тотализатора на лошадиных скачках. Начало ХХ в. подарило миру массу «женских» открытий: метод замораживания продуктов питания (1907 г., Мэри Инжел Пенингтон, США), посудомоечную машину, которая была «признана» необходимой вещью в хозяйстве лишь 40 лет спустя после открытия (1914, Ажозефин Хочрейн, США), глушитель для автомобиля (1917, Аолорес Ажонс, США), эмульсионный «корректор для опечаток» (американская машинистка Бэтти Грехем в 1956 г.), антибликовое стекло (Катрин Блодгетт, 1938), микроволновую печь (Ажесси Картрайт). Американские феминистки очень гордятся тем, что первой программисткой тоже была женщина - Ада $\Lambda$ авлейс» (Пушкарева, 2004: Электронный ресурс).

Характерно, что недооценка вклада женщин в науку является мировым трендом: физиолог Ф. Робштейн-Роббинс не была удостоена Нобелевской премии вместе с Аж. Х. Уипломом, хотя являлась соавтором всех его публикаций. То же можно сказать о Аизе Мейтнер, работавшей над проблемой расщепления атомного ядра с Отто Ганном. Аналогично, говоря о Пьере и Марии Кюри, мы сначала называем мужское имя.

Более того, специальные исследования показывают, что масса открытий, сделанных женщинами, были или недооценены их коллегами-мужчинами или были подтверждены исследованиями и представлены как собственные. В статье «10 сделавших инновационные открытия женщин-ученых, которые были вычеркнуты из истории» (10 сделавших ... : Электронный ресурс) приводятся следующие примеры: исследования Верь Рубин (г. р. 1928), которая смогла доказать, что орбитальная скорость звезд на отдаленных частях галактик соответствует скорости звезд в центре галактики, а также то, что 90\% вселенной заполнено темной материей. Магистерская и докторская диссертации Веры были проигнорированы и нашли признание через несколько десятилетий. Сесилия Пейн (1900-1979) - защитила докторскую диссертацию к 25 годам, открыв состав звезд. Ее руководитель Генри Норрис Рассел не рекомендовал ей публиковать результаты исследования. Спустя четыре года он представил научной общественности собственные научные результаты, которые полностью коррелировали с результатами Пейн. Сесилия Пейн в самые последние годы своей жизни была на- 
граждена премией имени Генри Норриса Рассела. Цзяньсюн Ву (1912-1997) помогла коллегам Чен Нин Яну и Цзун Аао $\Lambda$ выполнить эксперименты, опровергающие закон сохранения четности. Янг и $\Lambda$ и были удостоены Нобелевской премии за свое «открытие». Ву при этом не была даже упомянута. Нетти Стивенс (1862-1912) провела ряд опытов, доказывающих, что пол человека определяется 23-й парой хромосом, $\mathrm{X}$ и $\mathrm{Y}$. За разработки Нетти Нобелевскую премию получил Томас Морган, опубликовавший позже в журнале «Наука» статью, в которой он упомянул труд Стивенс как «технический», а не «научный». ИӘа Тэйк (1896-1978) открыла два новых химических элемента - рений (75) и мазурий (43). Последний сегодня известен как технеций, а его открытие закреплено за Карло Перриера и Эмилио Сегре. Эстер Аедерберг (1922-2006) вместе с мужем Ажошуа проводила исследования, за которые ее муж получил Нобелевскую премию, вклад же Эстер остался не признанным. Аиз Майтнер (1878-1968) - первой выдвинула гипотезу, связанную с процессом ядерного деления. Она передала результаты экспериментов Отто Гану и его партнеру Фрицу Стрэссмену, так как была вынуждена покинуть страну из-за насильственного присоединения Австрии к фашистской Германии. В 1944 г. ученым была присуждена Нобелевская премия, имя Майтнер не упоминалось, что позже было квалифицировано как «ошибка» - она была «исправлена» названием элемента номер 119 в честь Майтнер. Хенриетта Аивитm (1868-1921) - обосновала зависимость между яркостью звезды и ее расстоянием от Земли. Открытие $И$ ивитт стало основанием для выдвижения ее на Нобелевскую премию, но она скончалась до ее получения. Исследования $\Lambda$ ивитт были использованы известными учеными астрофизиками Харлоу Шэпли и Эдвардом Хубблом, которым Нобелевская премия была вручена за интерпретацию результатов. Ажоселин Белл Бернелл (1943 г. р.), работая с радиотелескопами, открыла сигналы, позже названные пульсарами, испускаемые нейтронными звездами. Удостоен же Нобелевской премии за открытие пульсаров в 1974 г. был Хьюиш, хотя впоследствии факт открытия пульсаров Ажоселин Белл Бернелл стал общепризнанным. Розалинд Франклин (1920-1958) в 33 года сделала открытие структуры АНК, состоящей из двух цепей и фосфатной основы. Без ведома Розалинд ее коллеги, Вилкинс и Перуц, показали ученым Уотсону и Крику рентгеновские снимки АНК и отчеты со всеми результатами. Уотсон убедил Розалинд издать свои результаты после них, таким образом, авторство и Нобелевская премия были получены Уотсоном и Криком, работы же Розалинд получили статус вторичных, подтверждающих результаты ученых (там же).

Осознавая тот факт, что эти данные, приведенные в статье о женщинах-ученых, вычеркнутых из истории, требуют дополнительного исследования, мы их все же приводим как основание для утверждения того, что роль женщины в науке гораздо больше, чем об этом принято говорить. И в том числе эти факты нам позволяют говорить о том, что устойчивый стереотип о несостоятельности и несамостоятельности женщин-политиков оказывается мифом.

\section{ЗАКАЮЧЕНИЕ}

Подводя итоги, отметим следующие факты. В науке России половину кадрового состава в таких научных отраслях, как химия, биология, география, медицина, сельское хозяйство, архитектура, фармакология, гуманитарные науки (кроме истории), составляют женщины. В то же время в физике, математике, механике и астрономии их число меньше в 1,5-2,5 раза (Выдающиеся женщины ..., 2012: Электронный ресурс). Среди тех, кто возглавляет научные школы и направления, - в основном мужчины, об 
академике Т. И. Заславской, главе новосибирской экономико-социологической школы, можно говорить, скорее, как об исключении. Сегодня женщин - действительных членов Российской академии наук всего 39, согласно спискам, находящимся в открытом доступе на сайте РАН. Из них преобладающее большинство: $\Lambda$. В. Адамян, Н. Н. Беседнова, Е. А. Корнева, И. В. Тарасевич, И. П. Анохина, И. М. Аонник, И. Н. Петрова - работают в области медицины, биологии, ветеринарии, сельского хозяйства.

Проблематика, разработкой которой занимаются известные российские женщины-философы, разнообразна. Среди ведущих философов страны П. П. Гайденко член-корреспондент РАН (проблема экзистенциального времени), Н. С. Автономова (эпистемология, философия и методология социального и гуманитарного познания), С. С. Неретина (познавательные модели средневековой философии), В. Г. Федотова (развитие гражданского общества в России), Н. В. Мотрошилова (социальная обусловленность познания), М. А. Степанянц (восточная философия), $\Lambda$. А. Маркова (проблема познавательного мышления в контексте постмодернистской и постаналитической философии).

Несмотря на то что любая статистика объективна, сама по себе она свидетельствует только о том, что женщинам совмещение чисто женских функций - например, функции материнства, и научной деятельности дается весьма сложно. Однако женщины - ученые и философы продолжают эффективно заниматься научными исследованиями, в том числе в традиционно «мужских» отраслях, - в России ежегодно с 2007 г. при участии Российской академии наук и Комиссии РФ по делам ЮНЕСКО проводится конкурс «Аля женщин в науке». В минувшем 2016 г. для участия в нем было подано 250 заявок из разных городов России. Признаны лучшими женщины-ученые из Института элементоорганических соединений им. А. Н. Несмеянова, Российской академии наук (ИНЭОС РАН), Южного федерального университета (физического факультета), Московского государственного университета им. М. В. Аомоносова (химического и биологического факультетов), Нижегородского государственного технического университета им. Р. Е. Алексеева (НГТУ), НИИ онкологии им. Н. Н. Петрова Минздрава России, Института цитологии Российской академии наук (ИНЦ РАН), Института биоорганической химии им. академиков М. М. Шемякина и Ю. А. Овчинникова РАН (ИБХ РАН), Научно-исследовательского института биомедицинской химии им. В. Н. Ореховича Российской академии медицинских наук (ИБМХ РАМН) (Плетнева: Электронный ресурс).

В разные годы аналогичными премиями были отмечены исследования по синтезу и использованию соединений молибдена, ниобия и тантала; работы по изучению микромицетов - грибков, повреждающих здания изнутри, микроорганизмов - симбионтов уникальных байкальских губок, фотоники металлоорганических комплексов; разработки наномаркера для отметки белковых молекул внутри организма и новых люминесцентных материалов; лекарственных препаратов на основе биомедицинской химии и методов дистанционного зондирования аэрозолей углекислого газа в спектрах планет земной группы (Выдающиеся женщины ..., 2012: Электронный ресурс).

Все это свидетельствует о том, что стереотипы и мифы в отношении женщин (в том числе в науке и философии), которые представлены массмедиа и устойчиво функционируют в массовом сознании, есть лишь привычная риторика, имеющая в значительной степени социальное основание. Аействительная же роль женщины в этих областях знания чрезвычайно высока и направлена на реализацию задач по освоению окружающего нас мира в интересах устойчивого и безконфликтного развития. 
СПИСОК АИТЕРАТУРЫ

Арифджанов, Р. (2007) В поисках женщин [Электронный ресурс] // Профиль. №37. URL: http://www.profile.ru/archive/item/54222-items_24277 (дата обращения: 01.12.2016).

Валянская, О. (2015) Женщина и философия [Электронный ресурс]// Журнал Пробеждення. 12 марта. URL: http://waking-up.org/razmyshleniya/zhenshhina-i-filosofiya/ (дата обращения: 10.09.2016).

Выдающиеся женщины-ученые (2012) [Электронный ресурс] // Наука и время. 16 июля. URL: http://novznania.ru/2012/07/ выдающиеся-женщины-ученые (дата обращения: 14.10.2016).

Миф о бездетности женщин-ученых [Электронный ресурс]// LiveJournal. URL: http://feministki.livejournal.com/2352656.html (дата обращения: 21.11.2016).

Мечников, И. И. (1988) Этюды оптимизма. М. : Наука. 328 с.

Нобелевский лауреат попал под гнев блогеров и СМИ за слова о женщинах-ученых [Электронный ресурс] // Medialeaks. URL: http://medialeaks.ru/news/1006mms_hunt (дата обращения: 10.09.2016).

Плетнева, Н. Красивые и умные женщины-ученые хотят зарплату повыше [Электронный ресурс]// Роснаука. URL: http://rosnauka.ru/publication/262 (дата обращения: 21.11.2016).

Пронин, А. А. (2008) Положение женщин в современной России: общая характеристика [Электронный ресурс]// Проза.Py. URL: http://www.proza.ru/2008/03/13/355 (дата обращения: 25.11.2016).

Пушкарева, Н. (2004) «Академики в чепце»? История дискриминационных практик в отношении российских женщин-ученых [Электронный ресурс]// Женщина Плюс. № 1. URL: http:// www.owl.ru/win/womplus/2004/01_11.htm (дата обращения: 25.11.2016).

Сычева, С. (2012) Женское лицо российской науки [Электронный ресурс]// S\&TRF. 7 марта. URL: http://www.strf.ru/material.aspx?CatalogId=221\&d_no=45603 (дата обращения: 25.11.2016).

Трусова, Ю. (2014) Спасти Мэтта Тейлора. Как за ученого вступились мужчины и женщины по всему миру [Электронный ресурс] // Medialeaks. 20 ноября. URL: http://medialeaks.ru/features/2010yt_taylor (дата обращения: 10.09.2016).

10 сделавших инновационные открытия женщин-ученых, которые были вычеркнуты из истории [Электронный ресурс]// MUZ4IN.net. URL: http://muz4in.net/news/10_sdelavshikh_innovacionnye_otkrytija_zhenshhin_uchjonykh_kotorye_byli_vycherknuty_iz_istorii/2013-10-1634261 (дата обращения: 24.09.2016).

Bushanan, R. T. (2015) Nobel prize winner Tim Hunt makes sexist remark, Katie Hopkins approves, internet despairs [Электронный ресурс]// The Independent. URL: http://www.independent.co.uk/news/people/nobel-prize-winner-tim-hunt-makes-sexist-remark-katie-hopkins-approvesinternet-despairs-10309543.html (дата обращения: 24.09.2016).

Buber, I., Berghammer, C., Prskawetz, A. (2011) Doing Science, Forgoing Childbearing? Evidence from a Sample of Female Scientists in Austria Österreichische Akademie der Wissenschaften [Электронный ресурс] // VID Working Paper. № 1. URL: http://www.oeaw.ac.at/fileadmin/subsites/Institute/VID/PDF/Publications/Working_Papers/WP2011_01.pdf (дата обращения: 29.11.2016).

Aата поступления: 09.01.2017 2.

WOMAN IN SCIENCE AND PHILOSOPHY: THE DOMINATING MYTHS AND REALITY

A. V. KOSTINA

MOSCOW UNIVERSITY FOR THE HUMANITIES

In this article the author defines several stereotypes which create a system of myths about female scientists and philosophers in society, analyses them and proves them to be groundless.

Myth № 1 «The main predestination of a woman is to combine the functions of wife and mother, and it is impossible for her to combine scientific research or philosophy studies with these key functions». Among Doctors of Science and especially Academicians there really are not so many women. But the small amount of women in science proves the fact that they tend to give up a career in science 
and opt for giving birth to and bringing up children in order to fulfill their natural functions. It is necessary to take into account the conditions of scientific development in different countries.

Myth № 2 «A female scientist or philosopher must be strong-willed, but all women are too emotional». Emotionality and even tears are typical of both women and men to the same extent, and the stereotype about women's excessive emotionality is a myth. Men are not usually subject to obstruction for excessive emotionality in the same way as women are, but, on the contrary, are likely to enjoy support of every kind.

Myth № 3 «A woman cannot be a genius. In science and philosophy there really are hardly any discoveries, made by women». The myth is nowadays supported by the position of masculine apologetics. It is much more difficult for a woman to obtain the same results as men do in science and philosophy, as a woman needs not only to prove her scientific competency, but also to retain the right for the scientific statement itself and for being included into scientific and philosophical discourse.

The article provides a number of discoveries, made in the world science by women and a list of names of famous female scientists. It is noted that the undervaluing of women's contribution into science is a global trend. Furthermore, special research shows that a lot of discoveries made by women have either been underestimated by their men-colleagues or supported by research and then presented as their own ones.

Women make a half the scientific personnel in such disciplines as chemistry, biology, geography, medicine, agriculture, architecture, pharmacy, humanities (except history) in Russia. It is really difficult to combine the typically feminine functions, for example being a mother, with scientific research. But female philosophers and scientists effectively continue to carry out scientific research.

Keywords: woman; stereotype; myth; gender; femininity; masculinity; woman in science; female philosopher

\section{REFERENCES}

Arifdzhanov, R. (2007) V poiskakh zhenshchin. Profil', no. 37 [online] Available at: http:// www.profile.ru/archive/item/54222-items_24277 (access date: 01.12.2016). (In Russ.).

Valianskaia, O. (2015) Zhenshchina $\overline{\mathrm{i}}$ filosofiia. Zhurnal Probezbdennia, Mart 12 [online] Available at: http://waking-up.org/razmyshleniya/zhenshhina-i-filosofiya/ (access date: 10.09.2016). (In Russ.).

Vydaiushchiesia zhenshchiny-uchenye (2012). Nauka i vremia, Julie 16 [online] Available at: http://novznania.ru/2012/07/vydaiushchiesia-zhenshchiny-uchenye (access date: 14.10.2016). (In Russ.).

Mif o bezdetnosti zhenshchin-uchenykh. LiveJournal [online] Available at: http://feministki.livejournal.com/2352656.html (access date: 21.11.2016). (In Russ.).

Mechnikov, I. I. (1988) Etiudy optimizma. Moscow, Nauka. 328 p. (In Russ.).

Nobelevskii laureat popal pod gnev blogerov i SMI za slova o zhenshchinakh-uchenykh. Medialeaks [online] Available at: http://medialeaks.ru/news/1006mms_hunt (access date: 10.09.2016). (In Russ.).

Pletneva, N. Krasivye i umnye zhenshchiny-uchenye khotiat zarplatu povyshe. Rosnauka [online] Available at: http://rosnauka.ru/publication/262 (access data: 21.11.2016). (In Russ.).

Pronin, A. A. (2008) Polozhenie zhenshchin v sovremennoi Rossii: obshchaia kharakteristika. Proza.Ru [online] Available at: http://www.proza.ru/2008/03/13/355 (access date: 25.11.2016). (In Russ.).

Pushkareva, N. (2004) «Akademiki v cheptse»? Istoriia diskriminatsionnykh praktik v otnoshenii rossiiskikh zhenshchin-uchenykh. Zhenshcbina Plius, no. 1 [online] Available at: http://www.owl.ru/ win/womplus/2004/01_11.htm (access date: 25.11.2016). (In Russ.).

Sycheva, S. (2012) Z Zhenskoe litso rossiiskoi nauki. S\&TRF, Mars 7 [online] Available at: http:// www.strf.ru/material.aspx?CatalogId=221\&d_no=45603 (access date: 25.11.2016). (In Russ.).

Trusova, Iu. (2014) Spasti Metta Teilora. Kak za uchenogo vstupilis' muzhchiny i zhenshchiny po vsemu miru. Medialeaks, November 20 [online] Available at: http://medialeaks.ru/features/2010yt_ taylor (access data: 10.09.2016). (In Russ.). 
10 sdelavshikh innovatsionnye otkrytiia zhenshchin-uchenykh, kotorye byli vycherknuty iz istorii. MUZ4IN.net [online] Available at: http://muz4in.net/news/10_sdelavshikh_innovacionnye_otkrytija_zhenshhin_uchjonykh_kotorye_byli_vycherknuty_iz_istorii/2013-10-16-34261 (access date: 24.09.2016). (In Russ.).

Bushanan, R. T. (2015) Nobel prize winner Tim Hunt makes sexist remark, Katie Hopkins approves, internet despairs. The Independent [online] Available at: http://www.independent.co.uk/ news/people/nobel-prize-winner-tim-hunt-makes-sexist-remark-katie-hopkins-approves-internetdespairs-10309543.html (access data: 24.09.2016).

Buber, I., Berghammer, C. and Prskawetz, A. (2011) Doing Science, Forgoing Childbearing? Evidence from a Sample of Female Scientists in Austria Österreichische Akademie der Wissenschaften. VID Working Paper, no. 1 [online] Available at: http://www.oeaw.ac.at/fileadmin/subsites/Institute/VID/PDF/Publications/Working_Papers/WP2011_01.pdf (access date: 29.11.2016).

Submission date: 09.01.2017.

Костина Анна Владимировна - доктор философских наук, доктор культурологии, професcop, декан факультета культуры и искусства Московского гуманитарного университета. Адрес: 111395, Москва, ул. Юности, д. 5. Тел.: +7 (499) 374-61-81. Эл. адрес: Anna_Kostina@inbox.ru

Kostina Anna Vladimirovna, Doctor of Philosophy, Doctor of Culturology, Professor, Dean, Faculty of Culture and Art, Moscow University for the Humanities. Postal address: 5, Yunosti St., Moscow, Russian Federation 111395. Tel.: +7 (499) 374-61-81. E-mail: Anna_Kostina@inbox.ru 